\title{
Insulin-like growth factor and insulin receptors in intestinal mucosa of neonatal calves
}

\author{
I P Georgiev, T M Georgieva, M Pfaffl ${ }^{1}$, H M Hammon \\ and J W Blum
} Division of Animal Nutrition and Physiology, Institute of Animal Genetics, Nutrition and Housing, Faculty of Veterinary Medicine, University of Berne,
Bremgartenstr 109a, CH-3012 Berne, Switzerland
'Institute of Physiology, FML-Weihenstephan, Center of Life and Food Sciences, Technical University of Munich, Weihenstephanerberg 3, D-85354
Freising-Weihenstephan, Germany
(Requests for offprints should be addressed to J W Blum; Email: juerg.blum@itz.unibe.ch)
(I P Georgiev and T M Georgieva are currently at Department of Veterinary Physiology and Physiological Chemistry, Faculty of Veterinary Medicine, Thracian
University, 6000 Stara Zagora, Bulgaria)

\begin{abstract}
Intestinal development is modified by age and nutrition, mediated in part by insulin-like growth factors (IGF-I, IGF-II) and insulin. We have investigated whether expression of IGF-I, IGF-II and insulin receptors (IGFIR, IGF-IIR and IR; measured by real-time RT-PCR) and binding capacity $\left(\mathrm{B}_{\max }\right)$ of IGF-IR, IGF-IIR and IR in the mucosa of the small and large intestine of neonatal calves are modified by age and different feeding regimes. In experiment 1, pre-term (GrP) and full-term ( $\mathrm{GrN})$ calves (after 277 and 290 days of pregnancy respectively) were killed immediately after birth before being fed; a further group of full-term calves were fed for 7 days and killed on day 8 of life $\left(\mathrm{GrC}_{1-3}\right)$. In experiment 2 , full-term calves were killed on day 8 after being fed first-colostrum for 7 days $\left(\mathrm{GrC}_{\max }\right)$, colostrum of the first six milkings for 3 days $\left(\mathrm{GrC}_{1-3}\right)$ or milk-based formula for 3 days $\left(\mathrm{GrF}_{1-3}\right)$. Intestinal sites differed with respect to expression levels of IGF-IR (duodenum>jejunum in $\mathrm{GrC}_{1-3}$; ileum $>$ colon, duodenum $\geq$ jejunum in $\mathrm{GrF}_{1-3}$ ), IGF-IIR (colon $>$ duodenum and ileum in $\mathrm{GrN}$ ), and IR (lowest in ileum in $\mathrm{GrP}$ and $\mathrm{CrN}$; highest in colon in $\mathrm{GrC}_{1-3}$ and $\mathrm{GrC}_{\max }$ ). They also differed with respect to $B_{\max }$ of IGF-IR (ileum and colon>duodenum and jejunum in GrP; ileum and colon>jejunum in $\mathrm{GrN}$; colon>jejunum in $\mathrm{GrC}_{1-3}$; lowest in jejunum in $\mathrm{GrF}_{1-3}$ ), IGF-IIR (duodenum and colon $>$ jejunum and ileum in GrP; duodenum $>$ ilem and colon>jejunum in $\mathrm{GrN}$; duodenum, jejunum and
\end{abstract}

colon>ileum in $\mathrm{GrC}_{\max }, \mathrm{GrC}_{1-3}$, and $\left.\mathrm{GrF}_{1-3}\right)$ and $\mathrm{IR}$ (ileum>duodenum, jejunum and colon in $\mathrm{GrC}_{\max }$, $\mathrm{GrC}_{1-3}$, and $\left.\mathrm{GrF}_{1-3}\right)$. There were significant differences between groups in the expression of IGF-IR $\left(\mathrm{GrF}_{1-3}>\right.$ $\mathrm{GrC}_{\max }$ and $\mathrm{GrC}_{1-3}$ in ileum), IGF-IIR ( $\mathrm{GrN}>\mathrm{GrP}$ and $\mathrm{GrC}_{1-3}$ in colon; $\mathrm{GrN}>\mathrm{GrC}_{1-3}$ in jejunum and total intestine), and IR ( $\mathrm{GrC}_{\max }>\mathrm{GrF}_{1-3}$ in colon) and in the $\mathrm{B}_{\max }$ of IGF-IR ( $\mathrm{GrP}>\mathrm{GrN}$ in colon; $\mathrm{GrC}_{\max }>\mathrm{GrF}_{1-3}$ in jejunum), IGF-IIR ( $\mathrm{GrN}>\mathrm{GrP}$ in duodenum, ileum and total intestine; $\mathrm{GrN}>\mathrm{GrC}_{1-3}$ in duodenum, ileum, colon and total intestine) and IR ( $\mathrm{GrN}>\mathrm{GrP}$ in total intestine; $\mathrm{GrC}_{1-3}>\mathrm{GrN}$ in ileum and total intestine). In addition, $\mathrm{B}_{\max }$ values of IGF-IR, IGF-IIR and IR were correlated with villus circumference, villus height/crypt depth and proliferation rate of crypt cells at various intestinal sites. There were marked differences in $B_{\max }$ of IGF-IR, IGF-IIR and IR dependent on mRNA levels, indicating that differences in $\mathrm{B}_{\max }$ were the consequence of differences in posttranslational control and of receptor turnover rates.

In conclusion IGF-IR, IGF-IIR and IR expressions and $\mathrm{B}_{\max }$ in intestinal mucosa were different at different intestinal sites and were variably affected by age, but not significantly affected by differences in nutrition. Receptor densities were selectively associated with intestinal mucosa growth.

Journal of Endocrinology (2003) 176, 121-132

\section{Introduction}

In calves, the first 2-3 postnatal weeks are well known to be characterized by high morbidity and mortality rates. Diseases especially of the gastrointestinal (GI) tract (GIT), such as severe diarrhea, are frequent and are often followed by fatal systemic diseases. Adaptations of the GIT and of its digestive functions are critical due to the change from primarily parenteral nutrition during the fetal stage to exclusively enteral nutrition. Insufficient morphological and functional adaptations of the GIT are considered to be of central etiological importance for GI diseases (Guilloteau et al. 1997). This is especially true for pre-term calves (S Bittrich, H M Hammon and J W Blum, unpublished 
observations). Better knowledge of factors that stimulate functional development of the GIT for adequate adaptation to the postnatal period is expected to reduce digestive disorders and to improve digestive efficiency, health status, well-being and growth performance.

Morphology and function of the GIT in the postnatal period are influenced by endogenous and exogenous factors. Among exogenous factors nutritional and nonnutritional (bioactive) factors that are ingested with colostrum play a major role, as has been shown in calves by several authors (Guilloteau et al. 1997, Bühler et al. 1998, Blättler et al. 2001, Blum \& Baumrucker 2002, Blum et al. 2002). Colostrum at the onset of lactation contains the greatest amount of bioactive substances, including growth factors and hormones to which the newborn calf - and primarily the GIT - is exposed (Blum \& Baumrucker 2002).

The somatotropic axis of neonatal calves is basically functioning, although it is not yet fully mature (Hammon \& Blum 1997). During the postnatal period insulin-like growth factor (IGF)-I becomes more important than IGF-II (Breier et al. 2000, Butler \& LeRoith 2001). The somatotropic axis and especially IGFs, besides insulin, is involved in GIT development and especially in proliferation and maturation of enterocytes (Laburthe et al. 1988, Schober et al. 1990, Odle et al. 1996, MacDonald 1999, Menard et al. 1999). It has been demonstrated that IGF-II and insulin are involved in the mechanisms governing the differentiation of intestinal epithelium while IGF-I is mostly associated with crypt cell proliferation (Jehle et al. 1999). In newborn calves mRNAs for IGF-I and IGF-II, for receptors of growth hormone, IGF-I (IGF-IR), IGF-II (IGF-IIR) and insulin (IR), and for IGF binding proteins 1-3 are found in the ileum (Pfaffl et al. 2002). Based on ligand binding assays, receptors for IGF-I, IGF-II and insulin are present in the GIT of neonatal calves (Baumrucker et al. 1994, Hammon \& Blum 2002). Therefore, IGFs and insulin ingested especially with colostrum (Odle et al. 1996, Xu et al. 1994, Blum \& Baumrucker 2002), IGFs produced in the GI wall, and IGFs and insulin circulating in blood plasma can affect GI morphology and function after binding to their respective mucosal receptors (Lund 1994, Fholenhag et al. 1997, Jehle et al. 1999, Simmons et al. 1999, Blum \& Baumrucker 2002). The effects of IGFs and insulin depend, at least in part, on receptor number and affinity, i.e. intestinal IGF-IR, IGF-IIR and IR may be involved in GIT development in pre-term calves. Because calves are born relatively mature compared with other species such as rats, mice and humans, differences with other species with respect to receptor numbers and thus of GIT responses to ingested food components can be expected, i.e. specific studies on IGF-IR, IGF-IIR and IR in calves are justified and needed.

This study was conducted to investigate binding capacity $\left(\mathrm{B}_{\max }\right)$ and mRNA levels of IGF-IR, IGF-IIR and IR in the mucosa of duodenum, jejunum, ileum and colon in calves born 14 days pre-term and in calves born at normal term (after 290 days of pregnancy), in full-term calves on day 8 of life after being fed for 7 days, and in full-term 8-day-old calves fed different amounts of colostrum or only a formula (and thus different amounts of bioactive substances such as IGFs and insulin) for 7 days. We have tested the following hypotheses: (1) that mRNA levels and $\mathrm{B}_{\max }$ of IGF-IR, IGF-IIR and IR are specifically regulated and associated; (2) that IGF-IR, IGF-IIR and IR concentrations at the mRNA and protein level immediately after birth in pre-term calves differ from those of calves born at full-term; (3) that there are variations in IGF-IR, IGF-IIR and IR at the mRNA level in pre-term and full-term neonatal calves at different intestinal sites; (4) that IGF-IR, IGF-IIR and IR at the protein and mRNA level change within the first days of life in full-term neonatal calves; (5) that differences in intake of bioactive substances such as IGFs and insulin (as a consequence of differences in amounts of ingested colostrum or by ingesting only a formula) modify IGF-IR, IGF-IIR and IR mRNA levels and $\mathrm{B}_{\max }$ of duodenum, jejunum, ileum and colon; and (6) that IGF-IR, IGF-IIR and IR correlate with histomorphometrical traits and with proliferation rates of intestinal epithelium of duodenum, jejunum, ileum and colon.

\section{Materials and Methods}

\section{Animals, husbandry, feeding and experimental design}

The experiments were performed according to the Swiss law on Animal Protection and the experimental procedures were approved by the Committee for Animal Experimentation of the Canton of Freiburg (GrangesPaccot, Switzerland), supervised by the Swiss Federal Veterinary Administration (Berne, Switzerland).

Experiment 1 Single-born calves $(n=19$; seven Red Holstein, six Simmenthal $\times$ Red Holstein, five Holstein Friesian and one Brown Swiss), originating from the Research Station, were assigned to three groups. Pre-term calves, born on day 277 of gestation after cows were injected with $500 \mu \mathrm{g}$ prostaglandin $\mathrm{F}_{2 \alpha}$ (Estrumate; Essex Pharma GmbH, Friesoythe, Germany) and $5 \mathrm{mg}$ Flumethason (Flumilar; Veterinaria AG, Zürich, Switzerland), were killed immediately after birth before being fed, i.e. on day 1 of life (GrP, $n=6)$. Full-term calves born after the normal duration of pregnancy (290 \pm 2 days) were either killed immediately after birth $(\mathrm{GrN}, n=6)$ or on day 8 of life $\left(\mathrm{GrC}_{1-3}, n=7\right)$.

Calves of the $\mathrm{GrC}_{1-3}$ group were held on straw in individual pens for 7 days. Colostrum for $\mathrm{GrC}_{1-3}$ calves was from cows from the Research Station milked twice daily and was separately stored at $-20{ }^{\circ} \mathrm{C}$ to make pools of milkings 1 to 6 for days 1,2 and 3 . Before feeding, colostrum was warmed to $40{ }^{\circ} \mathrm{C}$ and then immediately 
Table 1 Feeding plan for neonatal calves

\begin{tabular}{|c|c|c|c|c|}
\hline & & Group & & \\
\hline & $\begin{array}{l}\text { Fed amounts } \\
\text { (g/kg BW/day) }\end{array}$ & $\mathrm{GrC}_{\max }$ & $\mathrm{GrC}_{1-3}$ & $\mathrm{GrF}_{1-3}$ \\
\hline & & & & \\
\hline 1 & 60 & Colostrum 1st milking & $\begin{array}{l}\text { Colostrum 1st } \\
+2 \text { nd milking }\end{array}$ & Formula 1 \\
\hline 2 & 80 & Colostrum 1st milking & $\begin{array}{l}\text { Colostrum 3rd } \\
+4 \text { th milking }\end{array}$ & Formula 2 \\
\hline 3 & 100 & Colostrum 1st milking & $\begin{array}{l}\text { Colostrum 5th } \\
+6 \text { th milking }\end{array}$ & Formula 3 \\
\hline 4 & 100 & $\begin{array}{l}\text { Colostrum 1st milking } \\
+\mathrm{MR}(\mathrm{v} / \mathrm{v}=3: 1)\end{array}$ & MR & $M R$ \\
\hline 5 & 100 & $\begin{array}{l}\text { Colostrum 1st milking } \\
+M R(v / v=1: 1)\end{array}$ & MR & $M R$ \\
\hline 6 & 100 & $\begin{array}{l}\text { Colostrum 1st milking } \\
+M R(v / v=1: 3)\end{array}$ & MR & $M R$ \\
\hline 7 & 100 & $\begin{array}{l}\text { Colostrum 1st milking } \\
+M R(v / v=1: 3)\end{array}$ & MR & MR \\
\hline
\end{tabular}

Calves of $\mathrm{GrC}_{\max }$ were fed first-colostrum up to day 7 of life, calves of $\mathrm{GrC}_{1-3}$ were fed colostrum from milkings 1 to 6 during the first 3 days of life and then a milk replacer (MR; whose nutrient composition was similar to that of mature milk) and calves of $\mathrm{GrF}_{1-3}$ were fed a milk-based formula during the first 3 days of life and then a milk replacer. Calves were fed twice daily. The formula fed on days 1, 2 and 3 was milk-based and contained comparable amounts of nutrients as colostrum of day 1 (milking 1), day 2 (milking 3) and day 3 (milking 5) respectively, but contained only traces of growth factors and hormones such as IGF-I and insulin.

fed. From day 4 onwards calves were fed a milk replacer (MR) diluted with water $(100 \mathrm{~g} / 1$ water $)$ up to day 7 , mimicking usual husbandry conditions. The contents of colostrum from milkings 1 to 6 and the MR, together with the feeding plans have been published elsewhere (Blättler et al. 2001, Rauprich et al. 2000a,b). Calves were fed twice daily by bottle, beginning $2 \cdot 7 \pm 0 \cdot 7 \mathrm{~h}$ after birth. The ensuing feedings were at $8,24,32,48,56$, and $72 \mathrm{~h}$ after the first feeding. From day 4 to day 7 calves were fed daily at 0800 and $1600 \mathrm{~h}$. Starting on day 4 calves had free access to water. The MR (UFA-200-Natura; without antibiotics) was purchased from UFA AG (Sursee, Switzerland).

Experiment 2 Male calves $(n=21 ; 13$ Simmental $\times$ Red Holstein, four Brown Swiss and four Holstein Fresian) were raised at the Swiss Federal Station for Animal Production (Posieux, Switzerland). All calves were single born after a normal length of pregnancy (290 days) and normal parturition. They were obtained immediately after birth and held on straw litter in individual pens up to day 7 of life.

Calves were divided into three dietary groups $\left(\mathrm{GrC}_{\max }\right.$, $\mathrm{GrC}_{1-3}$ and $\mathrm{GrF}_{1-3}$ ), each consisting of seven animals. Calves of the $\mathrm{GrC}_{\max }$ group were fed twice daily during the first 3 days of life on pooled undiluted colostrum that was the first milking after parturition, and then on first-milked colostrum on days 4, 5, 6, and 7 that was diluted with $25,50,75$, and 75 parts of MR respectively
(Table 1). Calves of the $\mathrm{GrC}_{1-3}$ group received colostrum of milkings 1 to 6 (first 3 days of lactation) on the first 3 days of life and then MR (100 g/l water) up to day 7 . Calves of the $\mathrm{GrF}_{1-3}$ group were fed a milk-based formula during the first 3 days of life and MR ( $100 \mathrm{~g} / 1$ water) from day 4 to day 7 .

Calves were fed by plastic bottle twice daily. The total amounts of fed colostrum, formula and MR on days 1, 2, and 3-7 were $60 \mathrm{ml} / \mathrm{kg}$ body weight (BW), $80 \mathrm{ml} / \mathrm{kg}$ $\mathrm{BW}$, and $100 \mathrm{ml} / \mathrm{kg} \mathrm{BW}$ respectively. The first feeding was $2-4 \mathrm{~h}$ after birth, and then at $8,24,32,48,56$, and $72 \mathrm{~h}$ after the first feeding. Starting on day 4 calves were fed daily at 0800 and $1600 \mathrm{~h}$ and had free access to water.

Colostrum was collected from cows from the Research Station. Colostrum for $\mathrm{GrC}_{\max }$ calves was a pool of first milking after parturition. Colostrum for $\mathrm{GrC}_{1-3}$ calves was obtained before the start of the experiment from cows milked twice daily. Colostrum of milkings 1 to 6 was used to prepare individual pools which were separately stored in plastic bottles at $-20^{\circ} \mathrm{C}$. Before feeding, the colostrum was warmed to $40{ }^{\circ} \mathrm{C}$ and immediately fed. Calves of the $\mathrm{GrF}_{1-3}$ group were fed three different milk-based formulas during the first 3 days of life (for meals on days 1, 2, and 3 respectively), containing only traces of growth factors and hormones such as IGF-I, IGF-II and insulin, but had comparable amounts of nutrients as colostrum on day 1 (from milkings 1 and 2), day 2 (from milkings 3 and 4) and day 3 (from milkings 5 and 6). Milk formulas were produced in co-operation with UFA AG. They consisted 
Table 2 Composition of colostrum milkings, formula and milk replacer fed to calves during the first 7 days of life

\begin{tabular}{|c|c|c|c|c|c|c|c|}
\hline & \multicolumn{2}{|l|}{ Day 1} & \multicolumn{2}{|l|}{ Day 2} & \multicolumn{2}{|l|}{ Day 3} & \multirow{2}{*}{$\frac{\text { Days 4-7 }}{\text { Milk replacer }}$} \\
\hline & Colostrum $^{1}$ & Formula $^{2}$ & Colostrum & Formula & Colostrum & Formula & \\
\hline \multicolumn{8}{|l|}{ Parameters } \\
\hline Gross energy $(\mathrm{MJ} / \mathrm{kg})$ & $5 \cdot 4$ & $5 \cdot 4$ & $3 \cdot 9$ & $3 \cdot 2$ & $3 \cdot 8$ & $3 \cdot 6$ & $1 \cdot 7$ \\
\hline Crude protein $(\mathrm{g} / \mathrm{kg})$ & 109 & 123 & 58 & 53 & 49 & 46 & 21 \\
\hline Crude fat (g/kg) & 60 & 56 & 48 & 37 & 50 & 49 & 22 \\
\hline IGF-I $(\mu \mathrm{g} / \mathrm{kg})$ & 292 & 8 & 103 & 16 & 71 & 11 & 5 \\
\hline Insulin $(\mu \mathrm{g} / \mathrm{kg})$ & $20 \cdot 0$ & $2 \cdot 7$ & $2 \cdot 6$ & $1 \cdot 1$ & $1 \cdot 9$ & $1 \cdot 7$ & $0 \cdot 2$ \\
\hline
\end{tabular}

${ }^{1}$ Colostrum pools were prepared from 8 cows and the data are the sums of milkings 1 and 2, 3 and 4, and 5 and 6 on days 1,2 and 3 respectively. ${ }^{2}$ The formula contained (per $\mathrm{kg}$ ) calcium caseinate (86, 208 and $282 \mathrm{~g}$ on days 1, 2 and 3 respectively), lactalbumin (576, 245 and 80 g on days 1,2 and 3 respectively), milk fat $(267,262$ and 353 g double cream on days 1, 2 and 3 respectively), lactose (57, 271 and $271 \mathrm{~g}$ on days 1,2 and 3 respectively), and a mineral premix (14 g on days 1,2 and 3 respectively). The mineral prefix (per $\mathrm{kg}$ ) contained calcium (186 g), magnesium (224 g), sodium ( $31 \mathrm{~g})$, phosphorus (92 g), chlorine (48 g), iron (12 g), manganese ( $8 \cdot 1 \mathrm{mg})$, copper ( $1.6 \mathrm{mg})$, zinc $(7 \cdot 8 \mathrm{mg})$, iodine $(0 \cdot 03 \mathrm{mg})$, cobalt (0.02 $\mathrm{mg})$ and selenium $(0 \cdot 02 \mathrm{mg})$. ${ }^{3}$ The milk replacer contained (per kg) skim milk powder (550 g), whey (40 g), corn-derived products (dextrose, glucose, oat cream, starch; $\left.172 \mathrm{~g}\right)$, tallow (145 g), lard (44 g/kg), lecithin (as emulgator; $19 \mathrm{~g})$, calcium (12 g), phosphorus (7.5 g), magnesium (1.6 g), sodium (4.9 g), zinc (80 mg), manganese (60 mg), iron $(20 \mathrm{mg})$, copper $(8 \mathrm{mg})$, iodine $(3 \mathrm{mg})$, selenium $(0.5 \mathrm{mg})$, cobalt $(0.5 \mathrm{mg})$, vitamin A $(26.25 \mu \mathrm{mol}$ retinol equivalent/kg), cholecalciferol $(195 \mathrm{nmol} / \mathrm{kg})$, vitamin E $(360 \mu \mathrm{mol} \alpha$-tocopherol $/ \mathrm{kg})$, thiamine $(57 \mu \mathrm{mol} / \mathrm{kg})$, riboflavin $(21 \mu \mathrm{mol} / \mathrm{kg})$, vitamin B-6 $(59 \mu \mathrm{mol} / \mathrm{kg})$ and vitamin B-12 $(37 \mathrm{nmol} / \mathrm{kg})$.

${ }^{4}$ Nitrogen-free extracts in milk replacer contained (per kg) $710 \mathrm{~g}$ lactose (i.e. $336 \mathrm{~g}$ lactose/kg milk replacer on a dry matter basis).

of calcium caseinate (a gift from Emmi Milch AG, Lucerne, Switzerland), lactoalbumin (a gift from Emmi Milch AG), lactose (UFA AG), milk fat in the form of commercially available dairy double cream provided by the Agricultural Institute of the Canton of Fribourg, Grangeneuve/Posieux, Switzerland, and a vitamin and mineral premix (Provini S.A., Cossonay-Gare, Switzerland). The milk replacer (UFA-200 Natura; containing no antibiotics) was purchased from UFA AG and was prepared as a $100 \mathrm{~g} / 1$ solution. Composition of colostrum milkings, formula and milk replacer are presented in Table 2 .

To protect against infections calves were injected s.c. with $20 \mathrm{ml}$ of an immunoglobulin ( $\mathrm{IgG}$ ) formulation (Gammaserin, $100 \mathrm{~g} \mathrm{IgG/1;} \mathrm{E} \mathrm{Gräub} \mathrm{AG,} \mathrm{Switzerland).} \mathrm{In}$ addition, from day 2 of life they received chicken eggderived immunoglobulin containing high titers against rotavirus and pathogenic E. coli type K99 (Lohmann Animal Health, Cuxhaven, Germany) with each meal. The amounts per meal were as follows: $5 \mathrm{~g}$ on day $2,4 \mathrm{~g}$ on day $3,3 \mathrm{~g}$ on day $4,2 \mathrm{~g}$ on day 5 , and $1 \mathrm{~g}$ on days 6 and 7 .

\section{Intestinal tissue sampling}

Calves were slaughtered on day 8 of life or directly after birth ( $\mathrm{GrN}$ and $\mathrm{GrP}$ ), the abdominal cavity was opened and the GIT was immediately removed. Sections with a length of $15-20 \mathrm{~cm}$ that originated from the middle parts of different regions of the intestine - duodenum, jejunum, ileum and colon - were opened and washed with ice-cold saline. The mucosa was gently scraped, and was put into ice-cold buffer $(50 \mathrm{mM}$ Tris- $\mathrm{HCl} ; 6 \mathrm{mM} \mathrm{MgCl} 2,1 \mathrm{mM}$
EGTA; $\mathrm{pH}=7 \cdot 4$ ) for radioligand binding assays, or into TRIzol Reagent (Gibco BRL, Basle, Switzerland) before freezing in liquid nitrogen, and was stored at $-80{ }^{\circ} \mathrm{C}$ until analyzed for mRNA of IGF-IR, IGF-IIR and IR.

\section{Radioligand binding assays}

The materials used and the binding assay procedures have recently been described in detail (Hammon \& Blum 2002). Immediately after slaughter, the intestinal mucosa was homogenized using an Ultra-Turrax homogenizer (T25, Janke and Kunkel, Staufen, Germany) four times at low speed ( $8000 \mathrm{revs} / \mathrm{min})$. The homogenate was then centrifuged at $800 \mathbf{g}$ for $10 \mathrm{~min}$, the supernatant was centrifuged at $10000 \mathbf{g}$ for $10 \mathrm{~min}$, and then at $100000 \mathbf{g}$ for $1 \mathrm{~h}$ as described. The pellet was suspended in ice-cold buffer with a motor-driven Glass-Teflon homogenizer and the obtained membrane suspension was stored at $-80{ }^{\circ} \mathrm{C}$ until analyzed. For binding studies the protein concentration of mucosal membrane suspensions was measured using a kit (BCA Protein Assay Reagent; Pierce, Rockford, IL, USA). The linearity of protein concentration was tested for each receptor at different protein concentrations. The final protein concentration of the membrane suspension was adjusted to 100,50 and $200 \mu \mathrm{g}$ protein/ml for $\left[{ }^{125} \mathrm{I}\right] \mathrm{IGF}-\mathrm{I},\left[{ }^{125} \mathrm{I}\right] \mathrm{IGF}-\mathrm{II}$, and $\left[{ }^{125} \mathrm{I}\right]$ insulin binding studies respectively, to perform binding studies in a linear range. Receptors were defined based on differences in ligand binding affinities in competitive binding assays and based on ligand blots. For the quantification of binding of $\left.\left[{ }^{125-} \mathrm{I}\right] \mathrm{IGF}-\mathrm{I},{ }^{125-} \mathrm{I}\right] \mathrm{IGF}-\mathrm{II}$ and $\left[{ }^{125-} \mathrm{I}\right]$ insulin the radiolabeled ligand $(0.35 \mathrm{ng})$ was incubated with increasing concentrations of the unlabeled ligand IGF-I 
$\left(10^{-12}\right.$ to $\left.10^{-7} \mathrm{M}\right)$, IGF-II $\left(10^{-11}\right.$ to $\left.10^{-7} \mathrm{M}\right)$, and insulin $\left(10^{-12}\right.$ to $\left.10^{-6} \mathrm{M}\right)$ respectively, and $\mathrm{B}_{\max }$ and binding affinity (evaluated by determination of the 50\% inhibition $\left(\mathrm{IC}_{50}\right)$ of binding of the radioactive label by the unlabeled ligand) was calculated. In contrast to the previous study (Hammon \& Blum 2002), IR were best fitted to a model with one binding site. The human/bovine IGF-I was donated by Novartis AG (formerly Ciba Geigy AG), St Aubin, Switzerland, IGF-II was purchased from GroPep, Adelaide, Australia, and bovine insulin was purchased from Sigma, St Louis, MO, USA. IGF-I, IGF-II and insulin were iodinated with the Chloramine $\mathrm{T}$ method.

\section{Determination of receptor $m R N A s$}

Total RNA extraction from mucosa of duodenum, jejunum, ileum and colon was performed using TRIzol Reagent (Gibco BRL) and was resuspended in RNasefree water treated with diethyl pyrocarbonate (DEPC, Sigma-Aldrich Vertriebs GmbH, Deisenhofen, Germany). RNA integrity and purity were tested by measurement of optical density and by electrophoresis using ethidium bromide staining. Total RNA was then reverse transcribed into cDNA using random hexamer primers (AmershamPharmacia Biotech) as described (Pfaffl et al. 2002). Materials used and the procedures followed in RT-PCR assays were recently described in detail (Pfaffl et al. 2002). The primers for IGF-IR (forward primer: TTA AAA TGG CCA GAA CCT GAG; reverse primer: ATT ATA ACC AAG CCT CCC AC), IGF-IIR (forward primer: TAC AAC TTC CGG TGG TAC ACC A; reverse primer: CAT GGC ATA CCA GTT TCC TCC A) and IR (forward primer: TCC TCA AGG AGC TGG AGG AGT; reverse primer: GCT GCT GTC ACA TTC CCC A) were generated by Microsyth $\mathrm{GmbH}$ (Balgach, Switzerland). RT-PCR quantification was performed with the LightCycle System (Roche Molecular Biochemicals, Rotkreuz, Switzerland) using software package 3.3 (Roche Molecular Biochemicals). Absolute quantification was based on external recombinant DNA standards (Pfaffl et al. 2002) and values were expressed on a molar basis.

\section{Histomorphometrical analyses and cell proliferation of intestinal epithelia}

For the histomorphometrical analyses hematoxylin and eosin-stained slides were available. Analyses were conducted with a light microscope connected to a videobased, computer-linked system, as described by Bühler et al. (1998) and Blättler et al. (2001).

Cell proliferation was based on counting cells which incorporate 5-bromo-2'-deoxyuridine that was intravenously injected $1 \mathrm{~h}$ before euthanasia (Blättler et al.
2001). 5-Bromo-2'-deoxyuridine-labeled (mitotic) crypt cells were calculated relative to unlabeled crypt cells and served as an indicator of cell proliferation rate.

\section{Data evaluation and statistics}

For data analysis, the $\mathrm{IC}_{50}$ of radiolabeled binding by the unlabeled ligand and $\mathrm{B}_{\max }$ were calculated by weighted least squares curve fitting using the GraphPad computer program (GraphPad Software Inc., San Diego, CA, USA). The results from real-time RT-PCR quantification on Light Cycler are expressed in fmol mRNAs per $1 \mathrm{mg}$ total RNA. The $\mathrm{B}_{\max }, \mathrm{IC}_{50}$, mRNAs values, and $\mathrm{B}_{\max } /$ mRNA ratios are given as means \pm s.E.M. Group differences of $\mathrm{B}_{\max }, \mathrm{IC}_{50}$, and mRNAs were evaluated using the RANDOM and REPEATED methods of the MIXED procedure with an inter-animal random effect of differences between the animals and a correlation structure within animals (SAS 1995). Age (experiment 1), feeding (experiment 2), and gut segments were used as fixed effects within animals. Differences $(P<0 \cdot 05)$ were evaluated by least significant difference (LSD) $(t$-test). The $\mathrm{B}_{\max } / \mathrm{mRNA}$ ratios were analyzed by one-way ANOVA with repeated measurements using receptor type as a variable (SAS 1995). Differences $(P<0 \cdot 05)$ were evaluated by LSD ( $t$-test). The COR procedure of the SAS program was used (SAS 1995) for calculations of correlations (IGF-I, IGF-II and insulin receptor numbers with respective mRNA concentrations in intestinal mucosa) and for calculations of $\mathrm{B}_{\max }$ with intestinal histomorphometrical traits and with proliferation rates of intestinal epithelia.

\section{Results}

Experiment 1: concentrations of $m R N A$ and maximal binding capacities of IGF-IR, IGF-IIR and IR in the mucosa of duodenum, jejunum, ileum and colon in pre-term calves on day 1 and in full-term calves on day 1 and day 7 of life

Expression of IGF-IR (Table 3) was significantly different between intestinal sites (duodenum>jejunum in $\mathrm{GrC}_{1-3}$ ), but there were no significant group differences. Expression of IGF-IIR differed significantly between intestinal sites (colon>duodenum and ileum in $\mathrm{GrN}$ ) and between groups ( $\mathrm{GrN}>\mathrm{GrP}$ in colon; $\mathrm{GrN}>\mathrm{GrC}_{1-3}$ in jejunum, colon and total intestine). Although total RNA concentration was higher in $\mathrm{GrC}_{1-3}$ than in GrN, IGF-IIR mRNA concentrations per $\mathrm{g}$ wet tissue were still significantly higher in $\mathrm{GrN}$ than in $\mathrm{GrC}_{1-3}$ (data not shown). Expression of IR differed significantly between intestinal sites (in $\mathrm{GrP}$ and $\mathrm{GrN}$ it was lowest in ileum; in $\mathrm{GrC}_{1-3}$ it was highest in colon), but there were no significant group differences.

$\mathrm{B}_{\max }$ of IGF-IR (Table 4) differed significantly between intestinal sites (ileum and colon>duodenum and jejunum 
Table 3 Concentrations of mRNA (fmol/mg total RNA) for IGF-I, IGF-II and insulin receptors in intestinal mucosa of pre-term calves $(\mathrm{GrP})$, full-term calves $(\mathrm{GrN})$, and 8-day-old calves $\left(\mathrm{GrC}_{1-3}\right)$ (experiment 1$)$. Results are expressed as means and pooled S.E.M.

\begin{tabular}{|c|c|c|c|c|c|c|}
\hline & \multicolumn{3}{|l|}{ Group } & \multirow[b]{2}{*}{$\begin{array}{l}\text { Pooled } \\
\text { S.E.M. }\end{array}$} & \multicolumn{2}{|c|}{$\begin{array}{l}\text { Group differences } \\
(P \text { values })\end{array}$} \\
\hline & GrP & GrN & $\mathrm{GrC}_{1-3}$ & & $\begin{array}{l}\text { GrP vs } \\
\text { GrN }\end{array}$ & $\begin{array}{l}\mathrm{GrC}_{1-3} \\
\text { vs } \mathrm{GrN}\end{array}$ \\
\hline \multicolumn{7}{|l|}{ IGF-IR } \\
\hline Duodenum & $3 \cdot 25$ & $2 \cdot 96$ & $2 \cdot 15^{\mathrm{A}}$ & $0 \cdot 76$ & NS & NS \\
\hline Jejunum & $2 \cdot 56$ & $2 \cdot 02$ & $0 \cdot 84^{\mathrm{B}}$ & $0 \cdot 53$ & NS & NS \\
\hline lleum & $1 \cdot 88$ & $2 \cdot 07$ & $1 \cdot 56^{\mathrm{AB}}$ & $0 \cdot 55$ & NS & NS \\
\hline Colon & $2 \cdot 66$ & $3 \cdot 12$ & $1 \cdot 69^{\mathrm{AB}}$ & 0.63 & NS & NS \\
\hline Total intestine & $2 \cdot 59$ & $2 \cdot 55$ & $1 \cdot 53$ & $0 \cdot 30$ & NS & NS \\
\hline \multicolumn{7}{|l|}{ IGF-IIR } \\
\hline Duodenum & $0 \cdot 085$ & $0.063^{B}$ & $0 \cdot 022$ & $0 \cdot 013$ & NS & NS \\
\hline Jejunum & 0.077 & $0 \cdot 1^{\mathrm{AB}}$ & 0.035 & 0.02 & NS & 0.05 \\
\hline Ileum & $0 \cdot 05$ & $0.074^{\mathrm{B}}$ & $0 \cdot 028$ & $0 \cdot 01$ & NS & NS \\
\hline Colon & 0.072 & $0 \cdot 15^{\mathrm{A}}$ & 0.027 & 0.03 & $0 \cdot 01$ & $0 \cdot 001$ \\
\hline Total intestine & $0 \cdot 071$ & $0 \cdot 1$ & $0 \cdot 028$ & 0.009 & NS & $0 \cdot 01$ \\
\hline \multicolumn{7}{|l|}{ IR } \\
\hline Duodenum & $16 \cdot 9^{\mathrm{A}}$ & $11 \cdot 2^{\mathrm{AB}}$ & $9 \cdot 6^{\mathrm{AB}}$ & $3 \cdot 3$ & NS & NS \\
\hline Jejunum & $15 \cdot 3^{\mathrm{A}}$ & $12 \cdot 8^{\mathrm{A}}$ & $5 \cdot 8^{\mathrm{B}}$ & $3 \cdot 5$ & NS & NS \\
\hline lleum & $7 \cdot 2^{\mathrm{B}}$ & $5 \cdot 8^{\mathrm{B}}$ & $8 \cdot 2^{\mathrm{B}}$ & $1 \cdot 8$ & NS & NS \\
\hline Colon & $14 \cdot 6^{\mathrm{A}}$ & $14 \cdot 2^{\mathrm{A}}$ & $15 \cdot 3^{\mathrm{A}}$ & $4 \cdot 5$ & NS & NS \\
\hline Total intestine & $13 \cdot 5$ & $11 \cdot 5$ & $9 \cdot 7$ & $1 \cdot 8$ & NS & NS \\
\hline
\end{tabular}

Calves of GrP ( $n=6)$ were born 2 weeks pre-term (after 277 days of pregnancy) and those of GrN $(n=6)$ were born full-term (after 290 days of pregnancy) and were killed immediately after birth. Calves of $\mathrm{GrC}_{1-3}(n=7)$ were born full-term, fed colostrum derived from milkings 1 to 6 for 3 days and then milk replacer (whose nutrient content was similar to that of mature milk) up to day 7 and were killed on day 8 .

${ }_{A}^{A}, \mathrm{~B}$ Within a column means of IGF-IR, IGF-IIR and IR with different capital superscript letters are significantly different $(P<0 \cdot 05)$. NS, not significant $(P>0 \cdot 05)$.

in $\mathrm{GrP}$, ileum and colon>jejunum in $\mathrm{GrN}$; colon> jejunum in $\left.\mathrm{GrC}_{1-3}\right)$ and between groups $(\mathrm{GrP}>\mathrm{GrN}$ in colon). $\mathrm{B}_{\max }$ of IGF-IIR differed significantly between intestinal sites (duodenum and colon>jejunum and ileum in GrP; duodenum>ileum and colon $>$ jejunum in $\mathrm{GrN}$; duodenum, jejunum, and colon $>$ ileum in $\left.\mathrm{GrC}_{1-3}\right)$ and between groups $(\mathrm{GrN}>\mathrm{GrP}$ in duodenum, ileum, and total intestine; $\mathrm{GrN}>\mathrm{GrC}_{1-3}$ in duodenum, ileum, colon, and total intestine) and there was also a significant group $\times$ gut interaction. $B_{\max }$ of IR differed significantly between intestinal sites (ileum $>$ duodenum, jejunum and colon in $\mathrm{GrC}_{1-3}$ ) and between groups ( $\mathrm{GrN}>\mathrm{GrP}$ in total intestine; $\mathrm{GrC}_{1-3}>\mathrm{GrN}$ in ileum and total intestine) and there was a significant group $\times$ gut interaction.

Experiment 2: concentrations of $m R N A$ and maximal binding capacities of IGF-IR, IGF-IIR and IR in the mucosa of duodenum, jejunum, ileum and colon of 8-day-old calves fed different amounts of colostrum or a milk-based formula

Expression of IGF-IR (Table 5) was significantly different between intestinal sites (ileum $>$ colon, duodenum $\geq$ jejunum in $\left.\mathrm{GrF}_{1-3}\right)$ and there were significant group differences $\left(\mathrm{GrF}_{1-3}>\mathrm{GrC}_{\max }\right.$ and $\mathrm{GrC}_{1-3}$ in ileum). In addition, there was a significant group $\times$ gut interaction. Expression of IGF-IIR in intestinal mucosa did not differ significantly between different intestinal segments, but IGF-IIR expression in duodenum tended to be higher $(P<0 \cdot 1)$ in $\mathrm{GrC}_{\max }$ than in $\mathrm{GrC}_{1-3}$. Expression of IR was significantly different between intestinal sites (colon>duodenum, jejunum, ileum in $\mathrm{GrC}_{\max }$; colon> jejunum and ileum in $\mathrm{GrC}_{1-3}$ ) and between groups $\left(\mathrm{GrC}_{\max }>\mathrm{GrF}_{1-3}\right.$ in colon). There was also a significant group $\times$ gut segment interaction.

$\mathrm{B}_{\max }$ of IGF-IR (Table 6) was significantly different between intestinal sites (colon>jejunum in $\mathrm{GrC}_{1-3}$ and duodenum, ileum, and colon> jejunum in $\mathrm{GrF}_{1-3}$ ) and between groups $\left(\mathrm{GrC}_{\max }>\mathrm{GrF}_{1-3}\right.$ in jejunum). There was a significant group $\times$ gut interaction. $B_{\text {max }}$ of IGF-IIR was significantly different between intestinal sites (duodenum, jejunum and colon>ileum in all three groups), but there were no significant group differences. $\mathrm{B}_{\max }$ of IR was significantly different between intestinal sites (ileum > duodenum, jejunum and colon in all three groups) and tended to be different (though not significantly, $P<0 \cdot 1)$ between groups $\left(\mathrm{GrC}_{\max }>\mathrm{GrF}_{1-3}\right.$ in jejunum and total intestine; $\mathrm{GrC}_{\max }>\mathrm{GrC}_{1-3}$ in colon). 
Table 4 Binding capacities ( $\mathrm{B}_{\max ;}$ fmol/mg protein) of IGF-I, IGF-II and insulin receptors in intestinal mucosa of pre-term calves (GrP), full-term calves $(\mathrm{GrN})$, and 8-day-old calves $\left(\mathrm{GrC}_{1-3}\right)$ (experiment 1$)$. Results are expressed as means and pooled S.E.M.

\begin{tabular}{|c|c|c|c|c|c|c|}
\hline & \multicolumn{3}{|l|}{ Group } & \multirow[b]{2}{*}{$\begin{array}{l}\text { Pooled } \\
\text { S.E.M. }\end{array}$} & \multicolumn{2}{|c|}{$\begin{array}{l}\text { Group differences } \\
(P \text { values })\end{array}$} \\
\hline & GrP & GrN & $\mathrm{GrC}_{1-3}$ & & $\begin{array}{l}\text { GrP vs } \\
\text { GrN }\end{array}$ & $\begin{array}{l}\mathrm{GrC}_{1-3} \\
\text { vs } \mathrm{GrN}\end{array}$ \\
\hline \multicolumn{7}{|l|}{ IGF-IR } \\
\hline Duodenum & $7 \cdot 2^{\mathrm{B}}$ & $7 \cdot 9^{\mathrm{AB}}$ & $9 \cdot 3^{\mathrm{AB}}$ & $1 \cdot 28$ & NS & NS \\
\hline Jejunum & $6 \cdot 3^{\mathrm{B}}$ & $5 \cdot 1^{\mathrm{B}}$ & $7 \cdot 6^{\mathrm{B}}$ & $1 \cdot 11$ & NS & NS \\
\hline Ileum & $12 \cdot 2^{\mathrm{A}}$ & $11 \cdot 3^{\mathrm{A}}$ & $10 \cdot 7^{\mathrm{AB}}$ & $1 \cdot 89$ & NS & NS \\
\hline Colon & $15 \cdot 3^{\mathrm{A}}$ & $9 \cdot 8^{\mathrm{A}}$ & $12 \cdot 0^{\mathrm{A}}$ & $2 \cdot 38$ & $0 \cdot 05$ & NS \\
\hline Total intestine & $10 \cdot 2$ & $8 \cdot 5$ & $9 \cdot 7$ & $0 \cdot 98$ & NS & NS \\
\hline \multicolumn{7}{|l|}{ IGF-IIR } \\
\hline Duodenum & $176^{\mathrm{A}}$ & $232^{\mathrm{A}}$ & $56^{\mathrm{A}}$ & $21 \cdot 3$ & $0 \cdot 05$ & $0 \cdot 001$ \\
\hline Jejunum & $60^{\mathrm{B}}$ & $76^{C}$ & $63^{A}$ & $12 \cdot 7$ & NS & NS \\
\hline lleum & $66^{\mathrm{B}}$ & $139^{\mathrm{B}}$ & $19^{\mathrm{B}}$ & $11 \cdot 7$ & $0 \cdot 01$ & $0 \cdot 001$ \\
\hline Colon & $166^{\mathrm{A}}$ & $160^{\mathrm{B}}$ & $63^{A}$ & $21 \cdot 3$ & NS & $0 \cdot 001$ \\
\hline Total intestine & 119 & 151 & 51 & $12 \cdot 9$ & $0 \cdot 05$ & $0 \cdot 001$ \\
\hline \multicolumn{7}{|l|}{ IR } \\
\hline Duodenum & $1 \cdot 7$ & $3 \cdot 6$ & $5 \cdot 0^{\mathrm{B}}$ & 0.53 & NS & NS \\
\hline Jejunum & $0 \cdot 9$ & $2 \cdot 4$ & $4 \cdot 1^{\mathrm{B}}$ & 0.57 & NS & NS \\
\hline Ileum & $2 \cdot 4$ & $5 \cdot 8$ & $21 \cdot 6^{\mathrm{A}}$ & $1 \cdot 80$ & NS & $0 \cdot 001$ \\
\hline Colon & $3 \cdot 0$ & $3 \cdot 8$ & $3 \cdot 1^{\mathrm{B}}$ & $0 \cdot 61$ & NS & NS \\
\hline Total intestine & $1 \cdot 9$ & $3 \cdot 8$ & $8 \cdot 5$ & $0 \cdot 85$ & $0 \cdot 05$ & $0 \cdot 001$ \\
\hline
\end{tabular}

A,B,C Within a column means of IGF-IR, IGF-IIR and IR with different capital superscript letters are significantly different $(P<0 \cdot 05)$. NS, not significant $(P>0 \cdot 05)$.

For further details see footnote to Table 3 .

Comparisons between IGF-I, IGF-II and insulin receptors and relationships between intestinal mucosal $m R N A$ s and binding capacities of IGF-I, IGF-II and insulin receptors

In this section analyses were performed based on pooled data of all groups and all intestinal sites of both experiments. Concentrations of IR mRNA were the highest $(P<0 \cdot 001)$, and concentrations of IGF-IR mRNAs were higher $(P<0 \cdot 001)$ than mRNA levels of IGF-IIR (means for all groups: $2 \cdot 1 \pm 0 \cdot 1,0.052 \pm 0.005$ and $11.5 \pm 0.9 \mathrm{fmol} / \mathrm{mg}$ total RNA for IGF-IR, IGF-IIR and IR respectively). $\mathrm{B}_{\max }$ values were higher $(P<0 \cdot 001)$ for IGF-IIR than for IGF-IR and IR (means for all groups: $9 \cdot 6 \pm 0 \cdot 4,76 \cdot 8 \pm 5 \cdot 7$ and $6 \cdot 9 \pm 0 \cdot 7 \mathrm{fmol} / \mathrm{mg}$ protein for IGF-IR, IGF-IIR, and IR respectively). Ratios of $\mathrm{B}_{\max }$ (fmol/mg protein)/mRNA (fmol/mg total RNA) were higher $(P<0 \cdot 001)$ for IGF-IIR than for IGF-IR and IR (Fig. 1). Considering all three receptor types there was a negative correlation between $B_{\max }$ and mRNA $(\mathrm{R}=-0.72 ; \quad P<0.001 ;$ Fig. 1$)$. The $\mathrm{B}_{\max }$ values of IGF-IR in colon were negatively correlated with IGF-IR mRNA $(-0.44 ; P<0 \cdot 05)$, whereas $B_{\max }$ values of IGFIIR were positively correlated with the IGF-IIR mRNA concentration in total intestine $(r=0.4 ; P<0.001)$ and especially in jejunum $(r=0.49 ; P<0.01)$, ileum $(r=0.57$; $P<0 \cdot 001)$, and colon $(r=0 \cdot 47 ; P<0 \cdot 01)$. The $\mathrm{B}_{\max }$ values of IR were negatively correlated with IR mRNA levels in duodenum $(r=-0 \cdot 41 ; P<0 \cdot 05)$.
Correlations between IGF-I, IGF-II and insulin binding capacities with intestinal epithelial histomorphometric and proliferative measurements

For IGF-IR there was a positive correlation between $\mathrm{B}_{\max }$ and crypt cell proliferation rates in duodenum $(r=0.5$; $P<0 \cdot 01)$, but negative correlations between $\mathrm{B}_{\max }$ and villus circumference $(r=-0 \cdot 28 ; \quad P<0 \cdot 01)$ and villus height/crypt depth ratios $(r=-0 \cdot 22 ; P<0 \cdot 01)$ in total small intestine. For IGF-IIR, $\mathrm{B}_{\max }$ correlated positively with villus circumference in duodenum $(r=0.36 ; P<0 \cdot 05)$, jejunum $(r=0 \cdot 34 ; P<0 \cdot 05)$, and ileum $(r=0 \cdot 68 ; P<0 \cdot 001)$ and correlated positively with villus height/crypt depth ratios in duodenum $(r=0 \cdot 72 ; P<0 \cdot 001)$, jejunum $(r=0 \cdot 37$; $P<0 \cdot 05)$, and ileum $(r=0 \cdot 7 ; P<0 \cdot 001)$.

$\mathrm{B}_{\max }$ of IGF-IIR correlated negatively with crypt depth in duodenum $(r=-0 \cdot 66 ; P<0 \cdot 01)$, jejunum $(r=-0 \cdot 4$; $P<0 \cdot 05)$, ileum $(r=-0.61 ; \quad P<0 \cdot 01)$ and colon $(r=-0 \cdot 72 ; P<0 \cdot 001)$ and correlated negatively with the crypt cell proliferation rates in duodenum $(r=-0 \cdot 42$; $P<0.05)$, jejunum $(r=-0.45 ; \quad P<0.05)$, and ileum $(r=-0 \cdot 34 ; P<0 \cdot 1)$.

In ileum, $B_{\max }$ values of IR correlated negatively with villus circumference $(r=-0 \cdot 45 ; \quad P<0 \cdot 01)$ and with villus height/crypt depth ratios $(r=-0 \cdot 6 ; P<0 \cdot 001)$ and correlated positively with crypt depth $(r=0.53$; $P<0 \cdot 01)$ and crypt cell proliferation rates $(r=0 \cdot 37$; $P<0 \cdot 05)$. 
Table 5 Concentrations of mRNA (fmol/mg total RNA) for IGF-I, IGF-II and insulin receptors in intestinal mucosa of differently fed calves (experiment 2). Results are expressed as means and pooled S.E.M.

\begin{tabular}{|c|c|c|c|c|c|c|c|}
\hline & \multicolumn{3}{|l|}{ Group } & \multirow[b]{2}{*}{$\begin{array}{l}\text { Pooled } \\
\text { S.E.M. }\end{array}$} & \multicolumn{3}{|c|}{$\begin{array}{l}\text { Group differences } \\
\text { ( } P \text { values })\end{array}$} \\
\hline & $\mathrm{GrC}_{\max }$ & $\mathrm{GrC}_{1-3}$ & $\mathrm{GrF}_{1-3}$ & & $\begin{array}{l}\mathrm{GrC}_{\max } \\
\mathrm{vs} \\
\mathrm{GrC}_{1-3}\end{array}$ & $\begin{array}{l}\mathrm{GrC}_{\max } \\
\mathrm{vs} \\
\mathrm{GrF}_{1-3}\end{array}$ & $\begin{array}{l}\mathrm{GrC}_{1-3} \\
\text { vs } \\
\mathrm{GrF}_{1-3}\end{array}$ \\
\hline \multicolumn{8}{|l|}{ IGF-IR } \\
\hline Duodenum & $1 \cdot 62$ & $2 \cdot 15^{\mathrm{A}}$ & $2 \cdot 03^{\mathrm{B}}$ & $0 \cdot 38$ & NS & NS & NS \\
\hline Jejunum & $1 \cdot 38$ & $0 \cdot 84^{\mathrm{B}}$ & $0 \cdot 90^{C}$ & $0 \cdot 26$ & NS & NS & NS \\
\hline Ileum & $1 \cdot 71$ & $1 \cdot 56^{\mathrm{AB}}$ & $3 \cdot 03^{\mathrm{A}}$ & $0 \cdot 32$ & NS & $0 \cdot 05$ & $0 \cdot 05$ \\
\hline Colon & $1 \cdot 72$ & $1 \cdot 69^{\mathrm{AB}}$ & $1.98^{\mathrm{BC}}$ & $0 \cdot 48$ & NS & NS & NS \\
\hline Total intestine & $1 \cdot 62$ & $1 \cdot 53$ & $2 \cdot 07$ & $0 \cdot 21$ & NS & NS & NS \\
\hline \multicolumn{8}{|l|}{ IGF-IIR } \\
\hline Duodenum & $0 \cdot 050$ & $0 \cdot 022$ & $0 \cdot 030$ & $0 \cdot 012$ & NS & NS & NS \\
\hline Jejunum & $0 \cdot 023$ & 0.035 & $0 \cdot 018$ & $0 \cdot 005$ & NS & NS & NS \\
\hline Ileum & $0 \cdot 040$ & $0 \cdot 028$ & $0 \cdot 018$ & $0 \cdot 005$ & NS & NS & NS \\
\hline Colon & $0 \cdot 044$ & $0 \cdot 027$ & $0 \cdot 029$ & $0 \cdot 008$ & NS & NS & NS \\
\hline Total intestine & $0 \cdot 04$ & $0 \cdot 029$ & $0 \cdot 024$ & $0 \cdot 005$ & NS & NS & NS \\
\hline \multicolumn{8}{|l|}{ IR } \\
\hline Duodenum & $7 \cdot 7^{\mathrm{B}}$ & $9 \cdot 6^{\mathrm{AB}}$ & $14 \cdot 4$ & $2 \cdot 3$ & NS & NS & NS \\
\hline Jejunum & $5 \cdot 3^{B}$ & $5 \cdot 8^{B}$ & $8 \cdot 8$ & $2 \cdot 4$ & NS & NS & NS \\
\hline Ileum & $6 \cdot 9^{\mathrm{B}}$ & $8 \cdot 2^{\mathrm{B}}$ & $13 \cdot 9$ & $2 \cdot 5$ & NS & NS & NS \\
\hline Colon & $21 \cdot 2^{\mathrm{A}}$ & $15 \cdot 3^{\mathrm{A}}$ & $10 \cdot 4$ & $5 \cdot 5$ & NS & 0.05 & NS \\
\hline Total intestine & $10 \cdot 2$ & $9 \cdot 7$ & $12 \cdot 1$ & $1 \cdot 9$ & NS & NS & NS \\
\hline
\end{tabular}

Calves of $\mathrm{GrC}_{\max }$ were fed colostrum of first milking during 7 days, calves of $\mathrm{GrC}_{1-3}$ were fed colostrum for 3 days and those of $\mathrm{GrF}_{1-3}$ a milk-based formula (with similar nutrient contents as colostrum) for 3 days and then a milk replacer (whose nutrient contents were similar to that in mature milk) up to day 7 . Calves were killed on day 8.

$\mathrm{A}, \mathrm{B}, \mathrm{C}$ Within a column means of IGF-IR, IGF-IIR and IR with different capital superscript letters are significantly different $(P<0 \cdot 05)$. NS, not significant $(P>0.05)$.

\section{Discussion}

Comparisons and associations between $m R N A$ levels and $B_{\max }$ of IGF-I, IGF-II and insulin receptors

That overall expression levels of IGF-IR and IR mRNA were higher than those of IGF-IIR confirms our previous data in the ileum (Pfaffl et al. 2002). In agreement with other studies (Young et al. 1990, Heinz-Erian et al. 1991, MacDonald 1999, Hammon \& Blum 2002), binding capacities of IGF-IIR were consistently higher than those of IGF-IR and IR. As $B_{\max }$ values were highest and mRNA expression values were lowest for IGF-IIR, the ratios of $\mathrm{B}_{\max } / \mathrm{mRNA}$ were much higher in IGF-IIR than in IGF-IR and IR.

Whereas correlations between IGF-IR $\mathrm{B}_{\max }$ and mRNA were low, there was an overall negative corrrelation between IR mRNA and $B_{\max }$, but an overall positive correlation between IGF-IIR $B_{\max }$ and mRNA. Obviously, differences in $B_{\max }$ of IGF-IR, IGF-IIR and IR were the consequence of differences in posttranslational control and of receptor turnover rates.

Because affinities of binding for IGF-I, IGF-II and insulin were not different between intestinal sites and at different postnatal stages (data not shown), differences in $\mathrm{B}_{\max }$ were the result of different receptor numbers.

IGF-IR, IGF-IIR and IR concentrations at the $m R N A$ and protein level at different intestinal sites

Studies on site-specific and on postnatal variations of intestinal IGF-IR, IGF-IIR and IR have been reported in pigs, rabbits and rats (Schober et al. 1990, Young et al. 1990, Nowak et al. 1996, Staley et al. 1998). Differences in IGF and insulin receptor numbers at different intestinal sites as found in our calves have been reported in rats (Heinz-Erian et al. 1991, Buts et al. 1997, FernandezMoreno et al. 1997) and are consistent with our previous studies in calves (Baumrucker et al. 1994, Hammon \& Blum 2002). However, differences in $B_{\max }$ in intestinal sections were not accompanied by corresponding differences in mRNA expression.

To the best of our knowledge this is the first study that demonstrates differences in intestinal IGF-IR, IGF-IIR and IR expressions at different intestinal sites in calves. Based on our data, receptor-mediated effects of IGF-I, IGF-II, and insulin are, therefore, likely to be region-specific. 
Table 6 Binding capacities ( $\mathrm{B}_{\text {max }}$ fmol/mg protein) of IGF-I, IGF-II and insulin receptors in intestinal mucosa of differently fed calves (experiment 2). Results are expressed as means and pooled S.E.M.

\begin{tabular}{|c|c|c|c|c|c|c|c|}
\hline & \multicolumn{3}{|l|}{ Group } & \multirow[b]{2}{*}{$\begin{array}{l}\text { Pooled } \\
\text { S.E.M. }\end{array}$} & \multicolumn{3}{|c|}{$\begin{array}{l}\text { Group differences } \\
(P \text { values })\end{array}$} \\
\hline & $\mathrm{GrC}_{\max }$ & $\mathrm{GrC}_{1-3}$ & $\mathrm{GrF}_{1-3}$ & & $\begin{array}{l}\mathrm{GrC}_{\max } \\
\mathrm{vs} \\
\mathrm{GrC}_{1-3}\end{array}$ & $\begin{array}{l}\mathrm{GrC}_{\max } \\
\mathrm{vs} \\
\mathrm{GrF}_{1-3}\end{array}$ & $\begin{array}{l}\mathrm{GrC}_{1-3} \\
\text { vs } \\
\mathrm{GrF}_{1-3}\end{array}$ \\
\hline \multicolumn{8}{|l|}{ IGF-IR } \\
\hline Duodenum & $11 \cdot 1$ & $9 \cdot 3^{\mathrm{AB}}$ & $9 \cdot 0^{\mathrm{A}}$ & $1 \cdot 5$ & NS & NS & NS \\
\hline Jejunum & $10 \cdot 3$ & $7 \cdot 6^{\mathrm{B}}$ & $5 \cdot 0^{\mathrm{B}}$ & 1 & NS & $0 \cdot 01$ & NS \\
\hline lleum & 11 & $10 \cdot 7^{\mathrm{AB}}$ & $11 \cdot 7^{\mathrm{A}}$ & $1 \cdot 3$ & NS & NS & NS \\
\hline Colon & $13 \cdot 2$ & $12 \cdot 0^{\mathrm{A}}$ & $9 \cdot 8^{\mathrm{A}}$ & 1.9 & NS & NS & NS \\
\hline Total intestine & $11 \cdot 2$ & $9 \cdot 7$ & $8 \cdot 7$ & $0 \cdot 8$ & NS & NS & NS \\
\hline \multicolumn{8}{|l|}{ IGF-IIR } \\
\hline Duodenum & $63 \cdot 5^{\mathrm{A}}$ & $56 \cdot 1^{\mathrm{A}}$ & $48 \cdot 9^{\mathrm{A}}$ & $12 \cdot 8$ & NS & NS & NS \\
\hline Jejunum & $52 \cdot 9^{\mathrm{A}}$ & $63 \cdot 4^{\mathrm{A}}$ & $39 \cdot 2^{\mathrm{AB}}$ & $13 \cdot 4$ & NS & NS & NS \\
\hline lleum & $21 \cdot 4^{B}$ & $18 \cdot 8^{\mathrm{B}}$ & $23 \cdot 3^{\mathrm{B}}$ & $2 \cdot 8$ & NS & NS & NS \\
\hline Colon & $66 \cdot 8^{\mathrm{A}}$ & $63 \cdot 9^{\mathrm{A}}$ & $53 \cdot 4^{\mathrm{A}}$ & 12 & NS & NS & NS \\
\hline Total intestine & $50 \cdot 6$ & $50 \cdot 6$ & $41 \cdot 0$ & $6 \cdot 1$ & NS & NS & NS \\
\hline \multicolumn{8}{|l|}{ IR } \\
\hline Duodenum & $6 \cdot 8^{\mathrm{B}}$ & $5 \cdot 0^{\mathrm{B}}$ & $4 \cdot 3^{\mathrm{B}}$ & $0 \cdot 7$ & NS & NS & NS \\
\hline Jejunum & $6 \cdot 6^{\mathrm{B}}$ & $4 \cdot 1^{\mathrm{B}}$ & $1 \cdot 8^{\mathrm{B}}$ & $0 \cdot 9$ & NS & NS & NS \\
\hline lleum & $20 \cdot 9^{A}$ & $21 \cdot 6^{\mathrm{A}}$ & $20 \cdot 3^{A}$ & $2 \cdot 7$ & NS & NS & NS \\
\hline Colon & $7 \cdot 6^{\mathrm{B}}$ & $3 \cdot 1^{\mathrm{B}}$ & $4 \cdot 8^{\mathrm{B}}$ & $1 \cdot 3$ & NS & NS & NS \\
\hline Total intestine & $10 \cdot 7$ & $8 \cdot 5$ & $7 \cdot 8$ & $1 \cdot 6$ & NS & NS & NS \\
\hline
\end{tabular}

Additional investigations are needed to localize receptors within the intestinal wall. In species other than calves IGF-IIR are mainly concentrated in the intestinal epithelial cell layer, whereas IGF-IR are mostly present at the serosal surface (MacDonald 1999) and there is a high density of IGF-IR, IGF-IIR and IR in crypt cells (Laburthe et al. 1988, Buts et al. 1997, Jehle et al. 1999, MacDonald 1999).

IGF-IR, IGF-IIR and IR concentrations at the $m R N A$ and protein level immediately after birth in pre-term as compared with full-term calves

There were significant differences between GrP and GrN groups with respect to receptor expression only for the IGF-II receptor, whereas binding capacities differed with respect to all three receptor types. This supports the view that posttranslational regulation of IGF-I, IGF-II and insulin receptors is more important than regulation at the expression level. However, significant differences of $\mathrm{B}_{\max }$ were not seen at all intestinal sites, indicating that the regulation was site-specific. The fact that for IGF-IR the only significant differences in $\mathrm{B}_{\max }$ between pre-term and full-term newborn calves were seen in the colon was surprising because IGF-I is a ubiquitous growth factor, as shown in calves (Cordano et al. 1998) and has widespread effects (Kimble et al. 1999).

Changes of IGF-IR, IGF-IIR and IR at the protein and $m R N A$ level change within the first days of life in full-term neonatal calves

This study is probably the first to demonstrate changes of intestinal IGF-IIR mRNA levels in calves during the first week of life. In pigs, ontogenetic changes of IGF-IIR as well as of IGF-IR expression have been described in tissues other than the intestine (Peng et al. 1996). Furthermore, there were age-dependent changes in $\mathrm{B}_{\max }$ of IGF-IIR and IR in calves from 2 weeks before normal term up to day 8 of life. While $B_{\max }$ of IGF-IIR decreased after birth, $B_{\max }$ of IR increased, whereas $B_{\max }$ values of IGF-IR (except in the colon) were not significantly different during the first week of life. Thus, these receptors exhibited ontogenetic differences. Because IGF-IR and IR numbers in piglets and rabbits were highest at birth and then declined for 3-6 days (Schober et al. 1990, Nowak et al. 1996), there are obviously species differences with respect to the ontogenetic behavior of $B_{\max }$ of IGF-IR and IR. The general decrease in $\mathrm{B}_{\max }$ of IGF-IIR possibly reflected a decreasing postnatal role of IGF-II as shown in 


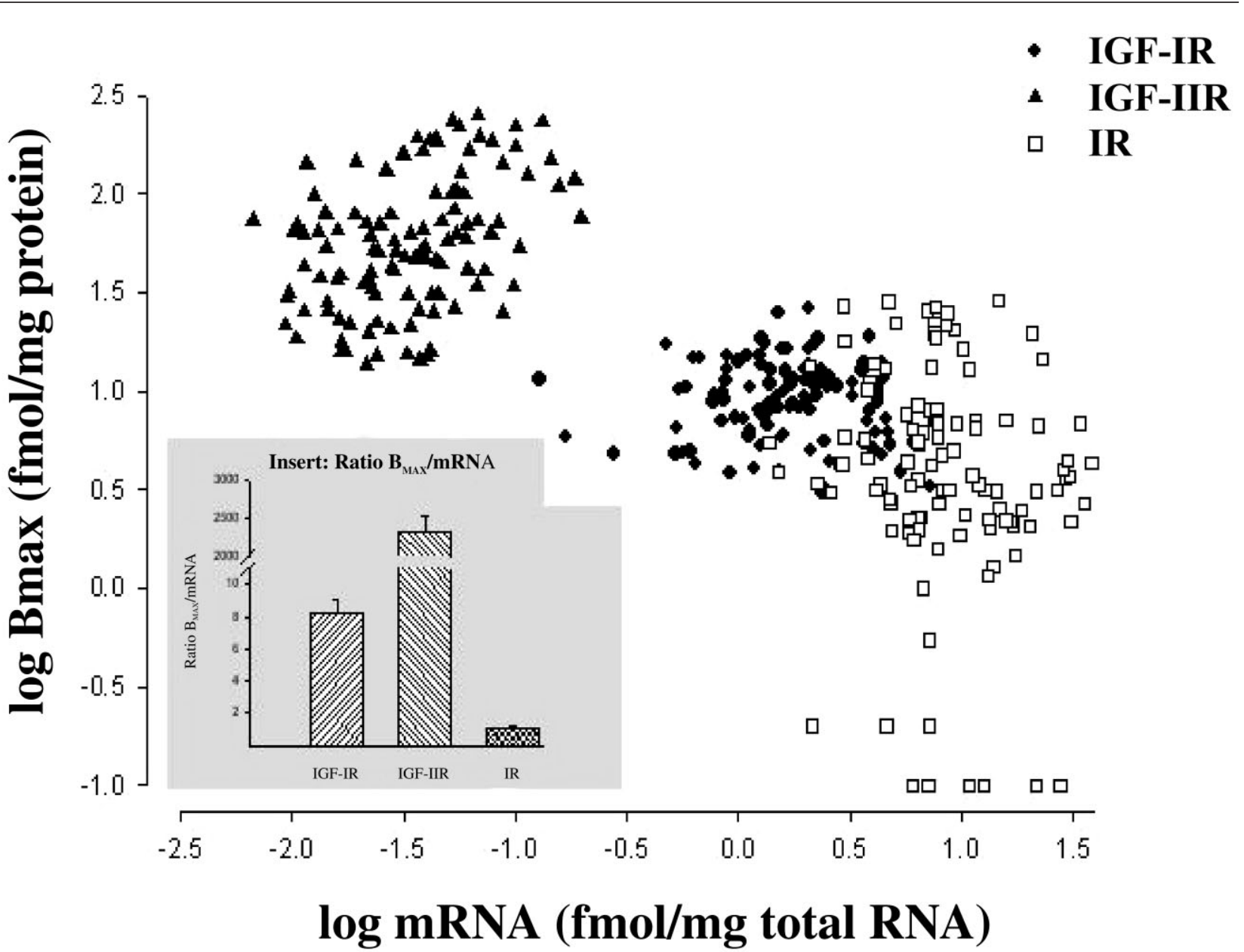

Figure 1 Binding capacities $\left(B_{\max }\right)$ for insulin-like growth factor-I (IGF-IR), insulin-like growth factor-II (IGF-IIR) and insulin (IR) receptors associated with mRNA levels of IGF-IR, IGF-IIR and IR. Insert: ratios of $B_{\max } / \mathrm{mRNA}$ for IGF-IR, IGF-IIR and IR in intestinal tissues.

rats (Nissley et al. 1993, Breier et al. 2000). The overall rise with age of $B_{\max }$ of IR in the small intestine, which was especially marked in the ileum from day 1 to day 8 of life, suggests involvement of IR in small intestine development (Nowak et al. 1996, Odle et al. 1996, Buts et al. 1997) and, in calves, especially in the ileum (Hammon \& Blum 2002).

Feeding effects on IGF-IR, IGF-IIR and IR $m R N A$ levels and $B_{\max }$ in full-term neonatal calves

This study could not demonstrate significant effects of differences in feeding during the first 7 days of life on intestinal expressions and on $\mathrm{B}_{\max }$ of IGF-IR, IGF-IIR and IR. However, the data showed a trend for reduced $B$ of IGF-IR, IGF-IIR and IR if calves were fed the formula rather than colostrum for 3 or 7 days. At first view this differs from our previous studies in which significant feeding effects on intestinal IGF-I, IGF-II and insulin receptor numbers have been described in neonatal calves
(Baumrucker et al. 1994, Hammon \& Blum 2002). Because the formula fed in the present study contained much higher amounts of protein and fat than the milk replacer fed in our previous study (Hammon \& Blum 2002), one explanation for the discrepancies between the earlier and the present experiments might have been differences in protein and energy intakes and, hence, probably the status of circulating IGF and insulin concentrations and possibly tissue levels of IGF and insulin receptors.

Despite marked differences in the ingestion of bioactive substances, such as IGF-I and insulin (and probably also of many other growth factors and hormones; Blum \& Baumrucker 2002), effects on $B_{\max }$ of IGF-IR, IGF-IIR and IR were weak. Therefore, the effects of orally ingested IGFs are variable because orally administered IGF-I for 7 days up-regulated intestinal IGF-IR numbers in neonatal calves (Baumrucker et al. 1994), whereas IGF-I administration down-regulated IGF-IR numbers in rats (Simmons et al. 1995). 
Correlations between IGF-IR, IGF-IIR and IR with histomorphometrical traits and with proliferation rates of intestinal epithelium

Data on intestinal histomorphological traits and of proliferation rates of enterocytes in calves investigated in the present study were published elsewhere (Blättler et al. 2001) or have been submitted for publication (Bittrich, H M Hammon and J W Blum, unpublished observations). Significant correlations of $\mathrm{B}_{\max }$ of IGF-IR, IGF-IIR and IR with villus circumference, villus height/crypt depth or with proliferation rates of crypt cells at various intestinal sites indicate that receptor densities were associated with GIT growth. Coefficients of correlation of $\mathrm{B}_{\max }$ of IGFIIR with villus circumference, villus height/crypt depth and proliferation rates were particularly high, suggesting that IGF-II and IGF-IIR may be of special importance for some intestinal sites in neonatal calves. Interestingly, IGF-IR and IR were positively correlated, whereas IGFIIR was negatively correlated with crypt cell proliferation rates. Negative correlations of IGF-IIR with crypt cell proliferation rates, but positive correlations of IGF-IIR with villus circumference and with villus height/crypt depth suggest that crypt cells and mature villus epithelial cells respond differently to IGFs. The IGF-II receptor serves IGF-II turnover and removal and thus may be involved in growth inhibition (Ludwig et al. 1996, Wolf et al. 1998, Nakae et al. 2001, Butler \& LeRoith 2001). Based on these facts, the hypothesis may be advanced that effects of IGF-II on crypt cells through IGF-IIR would be reduced while the stimulation of crypt cell proliferation by IGFs through the IGF-IR and IR would be maintained because growth stimulating effects by IGF-I and IGF-II have been shown to be completely mediated through and by IGF-IR, and to a lesser extent through the IR (Ludwig et al. 1996, Rother \& Accili 2000, Nakae et al. 2001). On the other hand, negative effects of IGF-II, mediated by the IGF-II receptor, on the proliferation of mature villus epithelial cells can be expected.

\section{Conclusions}

This study provides evidence that there are differences in IGF-IR, IGF-IIR and IR expression and $\mathrm{B}_{\max }$ at different intestinal sites and that these may be variably affected by age. IGF-IIR numbers and IGF-IIR mRNA levels were predominant in prenatal life and birth and then decreased, whereas $\mathrm{B}_{\max }$ of IR numbers increased in early postnatal life (especially in ileum). Ontogenetic variations of IGF-IR (except for colon), IGF-IR mRNA and IR mRNA were not pronounced. The data suggest that physiological effects of IGF-I, IGF-II and insulin on gut growth and function are variable in different intestinal regions and during different developmental periods. Marked differences in amounts of ingested colostrum or even the lack of colostrum intake for 7 days barely affect the expression and $\mathrm{B}_{\max }$ of IGF-IR, IGF-IIR and IR.

\section{Acknowledgements}

This study was supported by the Swiss National Science Foundation, CH-Berne (grants no. 32.051012.97 and 32-56823.99) and by H W Schaumann Foundation, D-Hamburg, We thank Lohmann Animal Health, Cuxhaven, Germany for providing the chicken-derived immunoglobulin.

\section{References}

Baumrucker CR, Hadsell DL \& Blum JW 1994 Effects of dietary insulin-like growth factor-I on growth and insulin-like growth factor receptors in neonatal calf intestine. Journal of Animal Science $\mathbf{7 2}$ $428-433$.

Blättler U, Hammon HM, Morel C, Philipona C, Rauprich A, Romé V, Le Huërou-Luron I, Guilloteau P \& Blum JW 2001 Feeding colostrum, its composition and feeding duration variably modify proliferation and morphology of the intestine and digestive enzyme activities of neonatal calves. Journal of Nutrition 131 1256-1263.

Blum JW \& Baumrucker CR 2002 Colostral insulin-like growth factors and related substances: mammary gland, and neonatal (intestinal and systemic) targets. Domestic Animal Endocrinology 23 101-110.

Blum JW, Hammon HM, Ontsouka E, Georgieva TM \& Georgiev IP 2002 Role of colostrum and milk components in the development of the intestine structure and function in calves. Biology of the Intestine in Growing Animals. In Developments in Animal and Veterinary Sciences. Eds SG Pierzynowski SG \& R Zabielski. Amsterdam, Elsevier. In Press.

Breier BH, Olivier MH \& Gallaher BW 2000 Regulation of growth and metabolism during postnatal development. In Ruminant Physiology: Digestion, Metabolism, Growth and Reproduction, pp 187-200. Ed PB Cronjé. New York: CABI Publishing.

Bühler C, Hammon H, Rossi GL \& Blum JW 1998 Small intestinal morphology in eight-day-old calves fed colostrum for different duration or only milk replacer and treated with long- $\mathrm{R}^{3}$-insulin-like growth factor I. Journal of Animal Science 76 758-765.

Butler AA \& LeRoith D 2001 Minireview: tissue-specific versus generalized gene targeting of the igf1 and igf1 $\mathrm{r}$ genes and their roles in insulin-like growth factor physiology. Endocrinology 142 1685-1688.

Buts JP, De Keyser N, Marandi S, Maernoudt AS, Sokal EM, Rahier J \& Hermans D 1997 Expression of insulin receptors and of 60-kDa receptor substrate in rat mature and immature enterocytes. American Journal of Physiology 273 G217-G226.

Cordano P, Hammon H \& Blum JW 1998 Tissue distribution of insulin-like growth factor I mRNA in 8-day-old calves. In Symposium on Growth in Ruminants: Basic Aspect, Theory and Practice for the Future, p 288. Eds JW Blum, T Elsasser \& P Guilloteau. Berne: University of Berne.

Cordano P, Hammon HM, Morel C, Zurbriggen A \& Blum JW 2000 mRNA of insulin-like growth factor (IGF) quantification and presence of IGF binding proteins, and receptors for growth hormone, IGF-I and insulin, determined by reverse transcribed polymerase chain reaction, in the liver of growing and mature male cattle. Domestic Animal Endocrinology 19 191-208.

Fholenhag K, Arrheinus-Nyberg V, Sjogren I \& Malmlof K 1997 Effect of insulin-like growth factor I (IGF-I) on the small intestine: a comparison between oral and subcutaneous administration in the weaned rat. Growth Factors 14 81-88. 
Fernandez-Moreno MD, Serrano-Rios M \& Prieto JC 1987 Identification of insulin receptors in epithelial cells from duodenum, jejunum, ileum, caecum, colon and rectum in the rat. Diabetes and Metabolism 13 135-139.

Guilloteau P, Le Huërou-Luron I, Chayvialle J, Toullec R, Zabierski R \& Blum JW 1997 Gut regulatory peptides in young cattle and sheep. Journal of Veterinary Medicine A 66 1-23.

Hammon H \& Blum JW 1997 The somatotropic axis in neonatal calves can be modulated by nutrition, growth hormone, and Long-R ${ }^{3}$-IGF-I. American Journal of Physiology 273 E130-E138.

Hammon HM \& Blum JW 2002 Feeding different amounts of colostrum or only milk replacer modify receptors of intestinal insulin-like growth factors and insulin in neonatal calves. Domestic Animal Endocrinology 22 155-168.

Heinz-Erian P, Kessler U, Funk B, Gais P \& Kiess W 1991 Identification and in situ localization of the insulin-like growth factor-II/mannose-6-phosphate (IGF-II/M6P) receptor in the rat gastrointestinal tract: comparison with the IGF-I receptor. Endocrinology 129 1769-1778.

Jehle PM, Fussgaenger RD, Blum WF, Angelus NK, Hoeflich A, Wolf E \& Jungwirth RJ 1999 Differential autocrine regulation of intestinal epithelial cell proliferation and differentiation by insulin-like growth factor (IGF) system component. Hormone Metabolic Research 31 97-102.

Kimble RM, Breier BH, Gluckman PD \& Harding JE 1999 Enteral IGF-I enhances fetal growth and gastrointestinal development in oesophageal ligated fetal sheep. Journal of Endocrinology 162 227-235.

Laburthe M, Rouyer-Fessard C \& Gammeltoft S 1988 Receptors for insulin-like growth factors I and II in rat gastrointestinal epithelium. American Journal of Physiology 254 G457-G462.

Ludwig T, Eggenschwiler J, Fisher P, D'Ercole AJ, Davenport ML \& Efstratiadis A 1996 Mouse mutants lacking the type 2 IGF receptor (IGF2R) are rescued from perinatal lethality in Igf2 and Igf1r null background. Developmental Biology 177 517-535.

Lund PK 1994 Insulin-like growth factors. In Gut Peptides: Biochemistry and Physiology, pp 587-612. Eds J H Walsh \& G J Dockray. New York: Raven Press.

MacDonald RS 1999 The role of insulin-like growth factors in small intestinal cell growth and development. Hormone Metabolic Research 33 103-113.

Menard D, Corriveau L \& Beaulieu JF 1999 Insulin modulates cellular proliferation in developing human jejunum and colon. Biology of the Neonate 75 143-151.

Nakae J, Kido Y \& Accili D 2001 Distinct and overlapping functions of insulin and IGF-I receptors. Endocrine Reviews 22 818-835.

Nissley P, Kless W \& Sklar M 1993 Developmental expression of the IGF-II/mannose 6-phosphate receptor. Molecular Reproductive Development 35 408-413.

Nowak JK, Styczynska E \& Slebodzinski AB 1996 Insulin receptors: the binding capacity and localization in the digestive tract during the rabbits neonatal period. Reproduction, Nutrition and Development 36 513-521.

Odle J, Zijlstra RT \& Donovan SM 1996 Intestinal effect of milk borne growth factors in neonates of agricultural importance. Journal of Animal Science 74 2509-2522.
Peng M, Pelletier G, Palin MF, Veronneau S, Le Bel D \& Abribat T 1996 Ontogeny of IGFs and IGFBPs levels and tissue concentration in liver, kidney and skeletal muscle of pig. Growth, Development, and Aging 60 171-187.

Pfaffl MW, Georgieva TM, Georgiev IP, Ontsouka E, Hageleit M \& Blum JW 2002 Real-time RT-PCR quantification of insulin-like growth factor (IGF)-I, IGF-I receptor, IGF-II, IGF-II receptor, insulin receptor, growth hormone receptor, IGF-binding proteins 1 , 2 and 3 in the bovine species. Domestic Animal Endocrinology 22 91-102.

Rauprich AB, Hammon H \& Blum JW 2000a Influence of feeding different amounts of first colostrum on metabolic, endocrine, and health status and on growth performance in neonatal calves. Journal of Animal Science 78 896-908.

Rauprich AB, Hammon H \& Blum JW $2000 b$ Effects of feeding colostrum and formula with nutrient contents as colostrum on metabolic and endocrine traits in neonatal calves. Biology of the Neonate 78 53-64.

Rother K \& Accili D 2000 Role of insulin receptors and IGF receptors in growth and development. Pediatric Nephrology 14 558-561.

SAS 1995SAS/STAT ${ }^{\circledast}$ User Guide (Release 6•11). SAS Inst. Inc., Cary, NC.

Schober DA, Simmen FA, Hadsel DL \& Baumrucker CR 1990 Perinatal expression of type I IGF receptors in porcine small intestine. Endocrinology 126 1125-1132.

Simmons JG, Hoyt EC, Westwick JK, Brenner DA, Pucilowska JB \& Lund PK 1995 Insulin-like growth factor-I and epidermal growth factor interact to regulate growth and gene expression in IEC-6 intestinal epithelial cells. Molecular Endocrinology 9 1157-1165

Simmons JG, Pucilowska JB \& Lund PK 1999 Autocrine and paracrine actions of intestinal fibroblast-derived insulin-like growth factors. American Journal of Physiology 276 817-827.

Staley MD, Gibson CA, Herbein JF, Grosvenor CE \& Baumrucker CR 1998 Rat milk and dietary long arginine 3 insulin-like growth factor I promote intestinal growth of newborn rat pups. Pediatric Research 44 512-518.

Wolf E, Hoeflich A \& Lahm H 1998 What is the function of IGF-II in postnatal life? Answers from transgenic mouse models. Growth Hormone and IGF Research 8 185-193.

Xu RJ, Birtles MJ, Breier BH \& Gluckman PD 1994 Effects of oral IGF-I or IGF-II on digestive organ growth in newborn piglets. Biology of the Neonate 66 280-287.

Young GP, Taranto TM, Jonas HA, Cox AJ, Hogg A \& Werther GA 1990 Insulin-like growth factors and the developing mature rat small intestine: receptors and biological actions. Digestion 46 (Suppl 2) 240-252.

Received 25 Sepember 2002

Accepted 1 October 2002 